\title{
Issues of Gay Community on the Novel of Simon VS the Homo Sapiens Agenda
}

\author{
Dewi Wijaya ${ }^{1 *}$, Irpan Ali Rahman ${ }^{2)}$ \\ ${ }^{1) 2)}$ Universitas Buddhi Dharma \\ Jl. Imam Bonjol No.41. Karawaci Ilir, Tangerang, Indonesia \\ 2) irpan.ali2@ubd.ac.id
}

Article history:

Received 10 May 2021; Revised 12 May 2021;

Accepted 13 May 2021;

Available online 15 May 2021

Keywords:

Rebecca

Shopping

Debts

Anxiety

Psychoanalysis

\begin{abstract}
The study aims to know how social community on gay's life through the novel of Simon vs the Homo sapiens agenda written by Becky Albertalli. The title of this research is "The Analysis of Main Character on Confessions of A Shopaholic Novel through Freudian Theory written by Sophie Kinsella". Confessions of A Shopaholic novel is tells about a women named Rebecca Bloomwood who has bad behavior that are shopping addiction to fulfill her desire but she gets anxiety because of her debts and it disturbs her psychological. This research will focuses on Rebecca's anxiety.The data are taken from the novel in the form of dialog and monolog. The writer using psychoanalysis theory from Sigmund Freud that related with anxiety theory. Sigmund Freud theory has 3 kinds of anxiety, there are realistic anxiety, neurotic anxiety and moral anxiety. This theory is used to analyze the cause and effect of Rebecca Bloomwood's anxiety.Last, the writer found the proved from Rebecca experiences three kinds of anxiety. First is neurotic anxiety caused by her mom character and it might be related to Rebecca childhood, Rebecca can't to be honest to her mom about the cost of her skirt or clothes, she always tells if they are cheap because she knows her mom will shocked and angry if she now the truth, that can related if Rebecca can't fulfill her desire when she was child because of her mom character. Second is realistic anxiety caused by her bad habit in shopping, that makes Rebecca has a lot of debts and that makes she becomes panic everytime met her debt collector. And the last moral anxiety caused by she felt guilty of her shopping behavior. And she becomes a liar to defense herself.
\end{abstract}

\section{INTRODUCTION}

It is quite hard to define what literature is in a concrete way. (Klarer, 2004) stated that the definition of literature has always been one that is closely related to "artistic" or "aesthetic" form of writing. It is what differentiates literature from other written works. Still, this does not give the exact definition of literature. Therefore, it will be more enlightening for literature to be seen as "cultural and historical phenomena and to investigate the conditions of their production and reception". Again, Klarer expressed, the purpose of the production of literature is to leave behind a trace of the writer's thoughts in hope that it will outlast the writer themselves.

Literature serves many different functions. It can be counted as a form of entertainment, a form of art, a form of values conveyance, a social document, etc. Novelist Nadine Gordimer once said that her writings do not deal with her convictions, but the society she lives and writes in (Gordimer, 1990). George Orwell also wrote in one of his essays that he writes because "there is some lie that I want to expose, some fact to which I want to draw attention, and my initial concern is to get a hearing" (Orwell, 1946). From all the quotations above, it can be concluded that literature is a written art which function not only as an entertainment but also a story and depiction of the society it is related with that the author wants to convey or reveal.

One of the famous forms of literature is novel. According to (Turnbull et al., 2010), novel is "a fictitious prose narrative of book length, typically representing character and action with some degree of realism". (Watt, 2000) in his book The Rise of the Novel explained that a novel clings to the experiences of its characters and is written in prose to authenticate its characters, locations, and events. Furthermore, he also stated that a novel allows the readers

\footnotetext{
${ }^{*}$ Corresponding author
} 
to feel both psychological closeness with the characters and even more, evaluate the author's musings or thoughts poured into the novel. A novel allows the readers to experience the events and transformations experienced by its characters first-hand (Gilman, 1989). From the discussions above, it can be concluded that a novel is a fictitious narrative written in everyday language which tells a story about its complex characters who are transformed by their experiences and in the journey of these transformations, there is no barrier between the characters and the readers, meaning the readers can relate to the characters in some ways or another.

There are many different issues a novel can address. One of those that are currently starting to become more widely read is LGBT (Lesbian, Gay, Bisexual, and Transgender) themed novels. LGBT signifies the diversity of sexual and gender identities. While the term is usually used in discussions to refer to the LGBT community as a whole, there are still differences in each term. Lesbian is a term used to describe a woman who is emotionally, sexually, and romantically attracted to another woman, whereas gay is the term used for a man who is attracted to another man. On the other hand, Bisexual refers to people who are emotionally, sexually, and romantically attracted to both woman and man. Transgender refers to "people whose gender identity (one's internal sense of gender) and gender expression (how one expresses outwardly that gender) is different from their sex at birth" (Movement Advancement Project, 2017). Due to the fact that the term encompasses many different subjects, a novel usually takes only one term to be its theme. For example is the gay-themed novel that will be analyzed in this study titled Simon vs the Homo Sapiens Agenda written by Becky Albertalli.

Simon vs the Homo Sapiens Agenda is published on 2015. Its plot is centered on a student named Simon and his online friend nicknamed Blue. Both of them are gay and struggling to tell their family and friends about it. Their relationship progresses as they converse with each other via e-mails. All is well until Martin, one of Simon's classmates, blackmails Simon after finding out that Simon is gay. Still feeling "awkward", as Simon phrases it in the novel, about disclosing his sexual orientation and wanting to protect Blue from being exposed, Simon decides to comply with Martin's requests. However, Martin still posts Simon and Blue's emails screenshots in the school's website, resulting in Simon's needing to disclose his sexual orientation in the cruelest way possible.

All in all, this novel shows a lot about gay people's decision to disclose their sexual orientation and how their relationships with the people around them affect their decision to disclose it. If only Simon had the sense of belonging and secureness he needed in telling his family and friends about his sexual orientation, perhaps it would not have been a disaster for him to be actually forced into admitting it. Hence the title, Sexuality Disclosure on Gay Community Depicted in Simon vs the Homo Sapiens Agenda Written by (Albertalli, 2015).

\section{METHODS}

The subject matter of this research is the sexuality disclosure for gay people as depicted in Simon vs the Homo Sapiens Agenda novel. The novel is written by (Albertalli, 2015) and published in 2015. The story focuses on the journey of the main character and his online friend in finding their courage to disclose their sexual orientation to their families and friends. The novel speaks a lot about the impact of the relationships and belongingness gay people have with the people around them in helping them to disclose their sexual orientation.

The writer chooses this novel because it depicts a relatable real life situation for gay people. It is popular among gay people in this era, especially who are still in their teens, and receives good responses and feedbacks from the readers. It was featured on the National Book Award Longlist and listed by the Wall Street Journal as one of the Best Young Adult novels in 2015. The novel has also been adapted into a film titled Love, Simon by 20th Century Fox in 2018, making history as the first film by a major studio focused on a gay teenage romance.

\section{RESULTS}

(Maslow, 1970) hierarchy of needs is a theory that explains people's nature to satisfy a specific and priority need. It specifies the steps of needs they need to climb and fulfill in order to reach the top of the hierarchy, self-actualization. When incorporated specifically to gay community, hierarchy of needs can as well depict the needs need to be fulfilled in order for gay people to disclose their sexuality. Here are the types of Need that Maslow's

\section{a. Physiological Needs}

This type of needs is the most basic needs people must fulfill in order to survive. A decent house, an enough amount of food and water every day, clothes to keep themselves warm, etc. Throughout the story, readers are shown that the gay people in the novel have already fulfilled their physiological needs. These are shown in the quotations below: 
... I have about an hour until dinner, which means an hour of trying to spin my school day into a string of hilarious anecdotes. My parents are like that. It's like you can't just tell them about your French teacher's obvious wedgie, or Garrett dropping his tray in the cafeteria. You have to perform it. Talking to them is more exhausting than keeping a blog. (Page 6)

From the monologue above, we know that the first gay character as well as the narrator in the novel, Simon, has the sufficient amount of basic needs human need to survive. He is waiting to enjoy a family dinner, which means he lives in a decent house for he himself admits the hilarious and jolly atmosphere his family has during dinner.

b. Safety Needs

The safety needs is one step higher than physiological needs. It does not only concern a person's ability to survive, but also to feel safe and secure both in internal or external factors. For gay community whose members are often victims of physical, emotional, or sexual abuse, safety needs are very important. It is the next level of needs they must fulfill in order to finally reach the comfortable and confident stage of disclosing their sexuality. In accordance to the gay people in the novel, because they are able to satisfy their physiological needs, they are now starting to fulfill their safety needs. However, having to pass and satisfy the safety needs is not easy. Even if they do satisfy their safety needs and advance to the next level of needs, it is not rare for them to go back into the safety needs.

\section{c. Belongingness in Family}

Back in section 4.2, it has been mentioned that Simon knows his family will not abandon or reject him if he ever choose to disclose his sexuality to them. In the case of Blue, his family is unpredictable thus resulting in him taking a gamble if he chooses to disclose his sexuality. Despite the significant difference in the safety needs they get from their families, both of them are still reluctant in disclosing their sexuality to their families. The reason why is because both of them lack belongingness in their own families.

Nora : "How about Daniel F.?" Nora asks, tucking a lock of hair behind her ear. Seriously, the piercings, I don't get her.

Alice $\quad$ : "Okay, Daniel F.'s the hottest one," says Alice.

Simon : My mom and Alice are always using the phrase "eye candy" to talk about these people.

Simon's Dad : “Are you kidding me?” my dad says. "The gay one?”

Nora : "Daniel's not gay,” Nora objects.

Simon's Dad : “Kid, he's a one-man Pride Parade. An eternal flame.”

Simon : My whole body tenses. Leah once said that she'd rather have people call her fat directly than have to sit there and listen to them talking shit about some other girl's weight. I actually think I agree with that. Nothing is worse than the secret humiliation of being insulted by proxy.

Alice : "Dad, stop," says Alice.

Simon : : And so Dad starts singing that song "Eternal Flame" by the Bangles. I never know if my dad says that kind of stuff because he means it, or if he's just trying to push Alice's buttons. I mean, if that's the way he feels, I guess it's good to know. Even if I can't unknown it. (Page 23-24)

The conversation in Simon's family above takes place when they were having their dinner. They were talking about an American reality show titled The Bachelorette when his father suddenly brought up and joked about one of the casts he thought was gay. This definitely piqued Simon's consciousness about his sexuality as he was trying to observe and confirm his family's view about homosexuality. Obviously, the way his father joked does not make him feel relieved. Instead, he grows wary and feels 'insulted' as he described in the way Leah feels when they talk about some girls' weight. This does not sit well with his needs for safety and more importantly, belongingness.

\section{d. Belongingness in Friends}

While family matters, knowing that people can count on friends will also help boosting one's confidence and sense of belonging. For gay people, belongingness in family and friends has the same equal importance, if not one more than the other, to resolve their decision to disclose their sexuality.

$\ldots$

Abby : "Yeah, and this is-maybe I'm reading this wrong, but he was talking about homecoming, and he brought it up like three times."

Simon : "Did he ask you to the dance?"

Abby : "No. It was like-I guess it seemed like he was maybe trying to?"

Simon : Martin freaking Adison. He's like the opposite of suave.

But holy fuck, I'm so relieved he didn't tell her. 
$\ldots$

Abby : "What about you? Are you still boycotting?" Abby asks.

Simon : "Of course." Leah, Nick, and I are of the mind that homecoming is just achingly lame, and we skip it every year.

Abby : "You could ask Leah," Abby says. She looks at me sidelong, with a weird, probing expression.

Simon : I feel a storm of laughter brewing. "You think I like Leah."

Abby : “I don't know," she says, smiling and shrugging. "You looked so sweet together tonight."

Simon : "Me and Leah?” I ask. But I'm gay. GAY. Gaaaaaaaayyyy. God, I should really just tell her. I can kind of picture her reaction. Eyes widening. Mouth falling open.

Yeah. Maybe not tonight. (Page 51-52)

In this dialogue between Simon and Abby, they were talking about their dance partner for the homecoming event at school. Upon brining the topic, Abby mentioned Martin and it surprised Simon. He was scared that Martin would tell Abby about the fact of him being gay. Therefore, when Abby said nothing gay-related, he felt so relieved. However, Abby's assumption of him liking Leah almost made Simon laugh. He also made sarcasm about just telling Abby his sexual orientation, and he also pictured Abby's reaction. When he predicted Abby's reaction and decided not to "maybe not tonight", it showed that Simon thought she would be utterly shocked. Again, this implies how Simon feels about their friendship. They are close, but not to the point of where he feels he belongs no matter what happen because his friends expect him to be straight. He knows that it will never cross his friends' mind about him being gay, thus it makes him reconsider disclosing his sexuality to them as well.

\section{e. Belongingness in Gay Community}

Gay people's lack of belongingness in family and friends make them turn to internet and social media to find a community where they feel they belong to, which is a gay community. Within this community, they do not have to worry about being accepted or rejected anymore. This is also what happens to the gay characters in the novel.

... My sister heard they donate money to screw over gay people, and I guess it started to feel weird eating there. Even if their Oreo milk shakes are giant vessels of frothy deliciousness. Not that I can bring that up with Nick and Leah. I don't exactly talk about gay stuff with anyone. Except Blue. (Page 8)

Quotation above is Simon who is feeling weird to eat at this one particular fast food restaurant because his sister told him the restaurant is not gay-people friendly. Despite not feeling comfortable to eat there, Simon couldn't tell Nick and Leah because telling them would result in his explaining the reason, thus he needed to disclose his sexuality to them. Furthermore, Simon admitted that he only talks about gay stuff to Blue, his online gay friend. The reason why Simon only talks to Blue about gay related things is because he feels connected with Blue, who is also gay.

\section{f. Esteem Needs}

Following the completion of the three previous needs is esteem needs. When members of gay communities have fulfilled all physiological, safety, and belongingness needs, not only they will be more confident in disclosing their sexuality but also they will gain the feeling of being worthy and appreciated. Although not much, the novel depicts this situation in the quotation below:

Simon :It's another note on blue-green construction paper, and it starts with a postscript. My fingers tremble as I read it.

Note from Blue : P.S. I love the way you smile like you don't realize you're doing it. I love your perpetual bed head. I love the way you hold eye contact a moment longer than you need to. And I love your moon-gray eyes. So if you think I'm not attracted to you, Simon, you're crazy.

Simon : And underneath that, he's written his phone number.

There's a tingling feeling that radiates outward from a point below my stomach-wrenching and wonderful and almost unbearable. I've never been so aware of my heartbeat. Blue and his vertical handwriting and the word "love" repeated over and over again.

Not to mention the fact that I could call him right this second and know who he is.

But I think I won't call. Not yet. Because, for all I know, he's waiting for me. For real. In person. Which means I have to get to the mall. (Page 262-263)

Above is the quotation taken when Simon got a gift as well as a note from Blue. In the note, Blue expressed how he adores Simon and even gave him his phone number. Simon, in response to Blue's confession, is feeling something he has never felt before. More importantly, he realized his self-worth and value as he is certain that Blue is waiting for him, that he is worth waiting for. This implies that Simon has self-esteem and he has also gotten the esteem he needs from others, in this case is from Blue. 


\section{g. Belongingness, Sexuality Disclosure, \& Heteronormativity}

In this section, the writer wants to explain more about why gay people feel the lack of belongingness in family, friends, or society in general. In chapter II, it has been explained that there is a view in society in which all people are assumed heterosexual and even setting heterosexuality as the default or the norm. This issue is also addressed in the novel and can be shown from the quotations below:

Honestly, the weirdest part is how they made it feel like this big coming out moment. Which can't be normal. As far as I know, coming out isn't something that straights kids generally worry about. ...

But I'm tired of coming out. All I ever do is come out. I try not to change, but I keep changing, in all these tiny ways. I get a girlfriend. I have a beer. And every freaking time, I have to reintroduce myself to the universe all over again. (Page 55-56).

The quotation above is told from Simon's point of view. He said that he was tired of coming out. In the society he lives in, or many other societies actually, heterosexual is still considered the norm. Usually in this type of society, those who do not fit the norm will be discriminated or alienated. This makes it hard for gay people to be themselves without having to tiptoe around. They still have the pressure from society.

\section{CONCLUSIONS}

It has been stated in the first chapter that the writer wanted to know how belongingness needs play a role in gay community's sexuality disclosure as depicted in Simon vs The Homo Sapiens Agenda written by Becky Albertalli. Using Abraham Maslow's hierarchy of needs incorporated to gay community's sexuality disclosure to analyze the novel, the writer finds three needs need to be fulfilled first which is physiological, safety, and belongingness needs. Among these three, the writer belongingness needs play a crucial role in gay people's decision making to disclose their sexuality in the novel.

Without disclosing their sexuality, members of the gay community will always need to hide and lie about themselves, their sexuality in particular. As a result of this, they will never advance to what Maslow called selfactualization which placed first in the hierarchy because to actualize oneself, they need to be sufficiently secure and confident and can be what they want to be.

Belongingness plays an important role in boosting gay people's decision in disclosing their sexuality. Lack of belongingness causes members of gay communities to feel unsure and cautious in sexuality disclosure. It makes them keep asking whether or not they will be accepted by family, friends, or society in general. It makes it hard for members of gay communities to disclose their sexuality. On the other hand, knowing that they are not alone, they connect with others, they belong somewhere, and they have someone to turn to will make them face the heteronormative view of society way braver and confident. As a result, it will also make gay people gain selfconfidence in disclosing their sexuality.

\section{REFERENCES}

Albertalli, B. (2015). Simon vs the Homo Sapiens Agenda. Balzer + Bray.

Gilman, S. (1989). The Novel According to Cervantes. University of California Press.

Gordimer, N. (1990). Conversations with Nadine Gordimer. University of Mississippi Press.

Klarer, M. (2004). An Introduction to Literary Studies (2nd Ed.). Routledge.

Maslow, A. H. (1970). Motivation and Personality (2nd Ed.). Harper \& Row.

Movement Advancement Project. (2017). Movement Advancement Project | An Ally's Guide to Terminology: Talking About LGBT People \& Equality. https://www.lgbtmap.org/allys-guide-to-terminology

Orwell, G. (1946). Such, Such Were the Joys. Harcourt Brace Jovanovich.

Turnbull, J., Lea, D., Parkinson, D., Phillips, P., Francis, B., Webb, S., Bull, V., \& Ashby, M. (2010). Oxford Advanced Learner's Dictionary, 8th Edition: Paperback. OUP Oxford. https://books.google.co.id/books?id=t90oQgAACAAJ

Watt, I. (2000). The Rise of the Novel. University of California Press. 